\title{
NARASI SIMBOL DAN MAKNA PADA TEKS SAWERAN PERNIKAHAN DESA KADU GEDONG KABUPATEN PANDEGLANG BANTEN SEBAGAI UPAYA MEMPERKAYA BAHAN PEMBELAJARAN SASTRA DI SMP
}

\author{
Ilmi Solihat ${ }^{1}$ dan Farid Ibnu Wahid ${ }^{2}$ \\ Pendidikan Bahasa Indonesia UNTIRTA \\ Email: ilmisolihat@untirta.ac.id
}

\section{Info Artikel}

Sejarah Artikel:

Diserahkan: 13-08-2021

Direvisi: 3-11-2021

Disetujui: 27-11-2021

\section{Keywords:}

Simbol, makna, dan teks saweran pernikahan

\section{Abstract}

This study was conducted to determine the functions and meanings contained in the traditional expression of the text of the Saweran wedding ceremony in Kadu Gedong Village, Pandeglang, Banten. The text studied is the kawih text, which will be analyzed with a semantic approach. The values of character education are also important points in this study, such as religious values, honesty, and tolerance in order to advance a person's basic potential to behave well and think positively, as well as develop the behavior of the nation's multicultural children. Furthermore, the results of the analysis of the narration of symbols and meanings in the Saweran text at the wedding ceremony in Kadu Gedong Village will be associated with existing competencies in junior high school, then a literary module, especially poetry learning, will be made. The results of the analysis show that first, the text of kawih saweran marriage has a function as a mandate to the bride and groom, and becomes a provision in the household, as well as a form of joy carried out by the two couples. Second, it has an inherent meaning, such as lexical meaning, direct meaning, figurative meaning, grammatical meaning, and cultural meaning. Third, it has character education values that are in accordance with the VII grade VII Junior High School learning implementation plan.

\begin{abstract}
Abstrak
Penelitian ini dilakukan untuk mengetahui fungsi dan makna yang terdapat pada ungkapan tradisional teks saweran upacara pernikahan Desa Kadu Gedong Pandeglang Banten. Teks yang dikaji adalah teks kawih, yang akan dianalisis dengan pendekatan semantik. Nilainilai pendidikan karakter juga menjadi poin penting dalam penelitian ini, seperti nilai religius, jujur, dan toleransi guna memajukan potensi dasar seseorang agar berperilaku baik serta berpikiran positif, serta mengembangkan perilaku anak bangsa yang multikultur. Selanjutnya hasil analisis narasi simbol dan makna dalam teks saweran pada upacara pernikahan di Desa Kadu Gedong akan dikaitkan dengan kompetensi yang ada di SMP, kemudian dibuatkan modul kesastraan khususnya pembelajaran puisi. Metode penelitian yang digunakan yaitu metode etnografi dengan tujuan memahami sudut pandang penduduk asli, hubungannya dengan kehidupan, untuk mendapatkan pandangannya mengenai dunianya. Hasil Analisis menunjukkan bahwa Pertama, teks kawih saweran pernikahan memiliki fungsi sebagai amanat kepada kedua mempelai, dan menjadi bekal dalam rumah tangga, serta sebagai bentuk suka cita yang dilakukan oleh kedua pasangan tersebut. Kedua, memiliki makna yang terkandung, seperti makna leksikal, makna langsung, makna kiasan, makna gramatikal, dan makna kultural. Ketiga, memiliki nilai-nilai pendidikan karaktrer yang sesuai dengan rencana pelaksanaan pembelajaran Sekolah Menengah Pertama kelas VII, di antaranya nilai religus, tanggung jawab, peduli sosial, dan lingkungan.
\end{abstract}

(C) 2021 Universitas Muria Kudus 


\section{PENDAHULUAN}

Keanekaragaman kebudayaan Indonesia, khususnya Sunda sangat menarik untuk dikaji dan diteliti. Dalam penyampaiannya, kebudayaan dapat divisualisasikan melalui bahasa. Dengan bahasa, maka kebudayaan dapat dikenal dan berkembang dalam masyarakat. Hal ini sejalan dengan Undang-Undang no. 5 Tahun 2017 tentang pemajuan kebudayaan. Dalam UU tersebut mengkhususkan pada suatu kebudayaan di Negara Republik Indonesia agar selalu dijaga dan dilestarikan di era modern ini. Dalam UU tersebut, menitik beratkan bahasa sebagai salah satu objek pemajuan kebudayaan yang tercantum dalam pasal 5 poin $\mathrm{h}$.

Bahasa merupakan sarana komunikasi untuk setiap individu berinteraksi agar tercipta suatu kehidupan. Bahasa juga memiliki peranan penting dalam kehidupan bermasyarakat. Selain itu, bahasa selalu menjadi identitas suatu komunitas atau etnis, budaya, serta agama. Bahasa juga memiliki peranan penting dalam kehidupan berpolitik serta dalam pelbagai kebudayaan, seperti kebudayaan pernikahan, syukuran, upacara adat, dan lain-lain.

Kegiatan Ungkapan Tradisional dalam upacara adat pernikahan Sunda biasanya dipimpin oleh seorang yang ahli, disebut juga juru sawér. Juru sawér biasanya orang yang mewakili orang tua pengantin dalam memberikan pepatah kepada pengantin dengan cara dilagukan. Biasanya bahasa yang dilagukan oleh juru sawér berupa pepatah orang tua kepada pengantin yang berisi tuntunan dalam berkehidupan rumah tangga. Lirik sawér biasa ditulis dalam bentuk syair, papantunan, dan pupuh.

Dalam tradisi Ungkapan Tradisional terdapat nilai-nilai luhur yang sangat penting dalam kehidupan. Salah satu nilai luhur yang sangat penting dan besar pengaruhnya dalam kehidupan adalah pendidikan. Pendidikan tidak hanya bisa diperoleh dari ilmu sains saja, melainkan pendidikan dari kearifan lokal pun besar pengaruhnya. Hal demikian disebut etnopedagogik.

Istilah "etnopedagogik" berasal dari kata etno dan pedagogik. Istilah etno berasal dari kata etnos, yang dalam bahasa Yunani berarti "generasi bangsa" atau "lokal". Pedagogik yaitu ilmu mengenai pendidikan dan pengajaran. Hal ini menjadi dasar etnopedagogik merupakan praktik pendidikan berbasis kearifan lokal dalam berbagai hal, seperti halnya cara mengobati penyakit, seni bela diri, lingkungan hidup, sistem pertanian, ekonomi, pemerintahan, sistem perbintangan, dan sebagainya. Maka dari itu, akan berkembang etnofilosofis, etnopsikologi, etno musikologi, etnopoliti, dan lain-lain.

Pada hakikatnya pendidikan bertujuan untuk "memanusiakan manusia". Rahmah (2020) menyebutkan bahwa pendidikan bertujuan untuk membentuk siswa yang berkarakter. Pendidikan bukan hanya transfer ilmu (transfer of knowladge), tetapi lebih jauh dari itu adalah transfer nilai (transfer of value), proses pendidikan yang dilatarbelakangi oleh budaya lokal itu sangat penting untuk dilaksanakan. Tujuannya agar pendidikan bisa membangun dan mewariskan nilai-nilai budaya lokal sebagai jati diri utama atau identitas suatu bangsa.

Keseragaman budaya pulalah yang menjadikan banyak perbedaan ketika melaksanakan upacara pernikahan. Terdapat banyak sekali perbedaan terlebih dalam pemberian amanat pada kedua mempelai, ada pula yang tidak memberikan amanat. Ketika pemberian amanat ini dilakukan, kedua mempelai harus mengerti tentang apa yang diamanatkan oleh orang tua mereka. Terkadang amanat tesebut berisikan beberapa wejangan dalam bahasa Sunda halus yang notabene jarang sekali dipergunakan oleh warga masyarakat di Desa Kadu Gedong Kabupaten Pandeglang Banten.

Berdasarkan penjelasan di atas, peneliti mencoba melakukan pengkajian terhadap Simbol dan makna teks saweran pernikahan di desa Kadu Gedong Kabupaten Pandeglang Banten sebagai Upaya memperkaya bahan pembelajaran di SMP.

Sebuah simbol dapat dikatakan sebagai sebuah instrumen pemikiran yang muncul karena adanya interaksi atau komunikasi di dalam masyarakat. Menurut Littlejohn (2009: 153) simbol adalah konseptualisasi manusia tentang suatu hal bahkan disebutkan bahwa sebuah simbol ada untuk sesuatu. Suatu tanda atau 
simbol merupakan suatu stimulus yang menandai kehadiran sesuatu yang lain, bahkan sesuatu yang baru dalam tatanan masyarakat. Dengan demikian, suatu tanda berhubungan erat dengan maksud tindakan yang sebenarnya (Morissan, 2013: 89). Sehingga dapat dipahami bahwa makna yang kita berikan kepada sebuah simbol merupakan produk dari interaksi sosial yang tergambar dari sebuah kesepakatan untuk menerapkan makna tersebut pada simbol tertentu.

Berkaitan dengan makna simbol yang muncul karena adanya interaksi sosial, etnolinguistik sebagai cabang ilmu linguistik memiliki cakupan yang luas antara bahasa dan budaya. Cakupan tersebut tidak dapat dimungkiri munculkan simbol dan makna yang baru di kalangan masyarakat. Kedua cakupan ini menarik banyak kaum akademisi untuk melakukan penelitian terkait dengan studi etnolinguistik, sehingga pelbagai pengetahuan baru akhirnya dihasilkan dari penelitian melalui kajian ilmu ini. Pengetahuan baru tersebut merupakan salah satu cara inventarisasi hasilhasil kebudayaan berbentuk bahasa yang telah ada di tengah-tengah masyarakat sejak dahulu hingga sekarang.

Pelbagai macam bentuk penelitian dengan kajian etnolinguistik terus berlanjut sesuai dengan pergerakan kebudayaan yang dinamis. Hal ini disebabkan karena setiap budaya baru akan menghasilkan bahasa atau tradisi lisan yang baru pula sesuai dengan zamannya. Namun demikian terdapat beberapa bahasa sebagai wujud budaya lampau yang masih berlaku di masa kini-disebut klasik, contohnya ungkapan tradisional dalam saweran.

Hasil kebudayaan berupa ungkapan tradisional dikatakan tahan zaman/klasik, karena masih berlaku dan sesuai jika diterapkan pada masa sekarang. Berdasarkan hal tersebutlah maka beberapa kajian etnolinguistik yang dilakukan oleh para akademisi ada yang meneliti tentang ungkapan tradisional. Demikian pula pada penelitian ini yang sifatnya melengkapi penelitian sebelumnya terkait dengan ungkapan tradisional. Dengan kata lain, penelitian ini mengacu pada penelitian-penelitian terdahulu yang sesuai dan dapat dijadikan sebagai kajian pustaka.

Etnolinguistik merupakan suatu sebuah kata yang polimorfemis. Ada dua kemungkinan analisis akan kata tersebut. Pertama, kata etnolinguistik dipandang dari kata ethnos yang berarti suku bangsa dan linguistics yang berarti ilmu bahasa. Kedua, kata etnolinguistik merupakan gabungan atas morfem etno dan morfem linguistik. Morfem etno itu sendiri merupakan kependekan dari kata etnologi, yaitu ilmu tentang unsur atau masalah kebudayaan suku bangsa dan masyarakat penduduk suatu daerah di seluruh dunia secara komparatif dengan tujuan mendapat pengertian ikhwal sejarah dan proses evolusi serta penyebaran kebudayaan umat manusia di muka bumi. Selanjutnya, kata linguistik dalam definisi sinoniminya merupakan ilmu bahasa.

Secara operasional, etnolinguistik dapat didefinisikan sebagai cabang linguistik yang dapat digunakan untuk mempelajari struktur bahasa dan/atau kosakata bahasa masyarakat etnis tertentu berdasarkan cara pandang dan budaya yang dimiliki masyarakat penuturnya dalam rangka menyibak atau mengungkap budaya masyarakat tersebut. Dalam hal ini, terkadang menyebut istilah etnolinguistik sama halnya dengan antropolinguistik. Akan tetapi, seperti yang tertera di dalam kamus besar bahasa Indonesia merupakan "ilmu tentang pertumbuhan manusia, bentuk dan sifat tubuh, faktor keturunan, dan sebagainya". Sedangkan menurut Sugono dkk (2008: 77) yang tidak hanya menyangkut budaya, tetapi juga aspek biologis. Jika kata antropologi akan dikaitkan dengan budaya, orang harus menambah dengan kata budaya, sehingga menjadi antropologi budaya.

Sawer pengantin itu merupakan bagian dari urutan adat istiadat perkawinan suku Sunda. Sawer atau nyawer berasal dari kata awer, yang artinya air jatuh menjiprat. Pengertian lain sawer itu adalah taweuran, yang artinya perkerjaan itu dilaksanakan di dalam panyaweran atau cucuran atap. Berhubung pengertiannya seperti itu yakni air jatuh menciprat atau cucuran atap, maka pelaksanaannya pun yang dilakukan oleh juru sawer seperti itu. Misalnya kalau pengertiannya 
sebagai air jatuh menjiprat, sesuai dengan pelaku juru sawer menjiprat-jipratkan atau menaburnaburkan perlengkapan benda-benda sawer ke arah pengantin yang dipayungi dengan payung besar kerajaan yang penuh hiasan yang menawan. Juru sawer selain menjiprat-jipratkan atau menabur- naburkan benda-benda perlengkapan sawer ke arah mempelai atau pengantin, dan juru sawer pun tak lupa pula menjiprat-jipratkan atau menabur- naburkan benda-benda perlengkapan sawer itu kepada hadirin yang ikut hadir memeriahkan di dalam pelaksanaan saweran. Yang akhirnya semua mendapat bagian dari benda-benda perlengkapan sawer, dengan cara berebutan untuk mendapatkannya serta dibarengi dengan soraksorai kegembiraan penuh ceria.

Selanjutnya, kalau pengertiannya sebagai panyaweran atau cucuran atap, maka sesuai dengan pengertiannya, juru sawer pun melaksanakan akan saweran tersebut selalu di panyaweran atau di cucuran atap. Oleh karena pengertiannya sebagai air jatuh menjiprat dari panyaweran atau cucuran atap, maka pelaksanaan yang dilakukan oleh juru sawer pun seperti itu, menjiprat-jipratkan atau menaburnaburkan benda-benda perlengkapan sawer ke arah pengantin dan hadirin, juga tempatnya selalu di atas panyaweran atau cucuran atap.

Isi atau makna dari sawer itu adalah nasihat, petuah atau wasiat dari orang tuanya yang diwakilkan kepada juru sawer. Mungkin ada orang yang penasaran atau ingin tahu, mengapa wasiat itu disebut sawer? Hal itu disebut demikian karena penyampaian wasiat itu dilaksanakan pada tempat cucuran atap atau panyaweran, sebagaimana penjelasan di atas. Maksudnya, wasiat dilakukan di sana (panyaweran) agar isi wasiat atau nasihat itu selain terdengar oleh kedua mempelai juga terdengar oleh khalayak yang mendengarkannya, baik oleh yang muda maupun oleh yang sudah tua. Khususnya, kepada orang yang sudah tua agar wasiat tersebut mereka teringat kembali sebagai makna bernostalgia.

Kata semantik dalam bahasa Indonesia (Inggris: semantics) berasal dari bahasa Yunani sema (kata benda) yang berarti tanda atau lambang. Kata kerjanya adalah semaino yang berarti "menandai" atau "melambangkan". Yang dimaksud dengan tanda atau lambang disini sebagai padanan kata dari sema itu adalah tanda linguistik. Seperti yang dikemukan oleh Ferdinand De Saussure (Chaer, 2012: 285) bahwa setiap tanda linguistik terdiri dari dua komponen yaitu: (1) komponnen yang mengartikan yang berwujud bentuk-bentuk bunyi bahasa. Misalnya, (Perancis: significant, Inggris: signifier) dan (2) komponen yang diartikan atau makna dari komponen pertama. Misalnya, (Perancis: signifie, Inggris: signified) sebenarnya tidak lain daripada konsep atau makna sesuatu tanda bunyi. Kedua komponen ini adalah merupakan tanda atau lambang, sedangkan yang ditandai atau yang dilambanginya adalah sesuatu yang berada diluar bahasa yang lazim disebut referen atau hal yang ditunjuk.

Kata semantik itu kemudian disepakati sebagai istilah yang digunakan untuk bidang linguistik yang mempelajari hubungan antara tanda-tanda linguistik dengan hal-hal yang ditandainya. Atau dengan kata lain, bidang studi linguistik yang mempelajari makna atau arti bahasa. Oleh karena itu, kata semantik dapat diartikan sebagai ilmu tentang makna atau arti, yaitu salah satu dari tiga tataran analisis bahasa: fonologi, gramatikal dan semantik.

Selain istilah semantik dalam sejarah linguistik ada pula digunakan istilah lain seperti semiotika, semiologi, semasiologi, sememik, dan semik untuk merujuk pada bidang studi yang mempelajari makna atau arti dari suatu tanda atau lambang. Namun, istilah semantik lebih umum digunakan dalam studi linguistik karena istilah-istilah yang lainnya itu mempunyai cakupan objek yang lebih luas, yakni mencakup makna tanda atau lambang pada umumnya. Termasuk tanda-tanda lalu lintas, kode morse, dan tanda-tanda ilmu matematika. Sedangkan cakupan semantik hanyalah makna atau arti yang berkenaan dengan bahasa sebagai alat komunikasi verbal.

Semantik memegang peranan penting dalam berkomunikasi. Karena bahasa yang digunakan dalam berkomunikasi adalah tidak lain untuk menyampaikan suatu makna (Sutedi, 
2003: 103). Misalnya seseorang menyampaikan ide dan pikiran kepada lawan bicara, lalu lawan bicaranya bisa memahami yang disampaikan. Hal ini disebabkan karena ia bisa menyerap makna yang disampaikan dengan baik.

\section{METODE PENELITIAN}

Penelitian ini menggunakan metode etnografi. Etnografi merupakan pekerjaan mendeskripsikan suatu kebudayaan termasuk di dalamnya kesenian pada masyarakat tertentu. Berikut ini akan dipaparkan lebih lanjut mengenai etnografi. Tujuan utama aktivitas ini adalah untuk memahami suatu pandangan hidup dari sudut pandang penduduk asli, sebagaimana dikemukakan oleh Bronislaw Malinowski (Spradley 2007: 4), bahwa tujuan etnografi adalah "memahami sudut pandang penduduk asli, hubungannya dengan kehidupan, untuk mendapatkan pandangannya mengenai dunianya”. Oleh karena itu, penelitian etnografi melibatkan aktivitas belajar mengenai dunia orang yang telah belajar, melihat, mendengar, berbicara, berpikir, dan bertindak dengan cara yang berbeda. Jadi, etnografi tidak hanya mempelajari masyarakat, tetapi lebih dari itu. Etnografi belajar dari masyarakat (Spradley, 2007: 4).

Penelitian ini menggunakan sumber data dari partisipan berupa kata-kata, tindakan, dan data tambahan seperti dokumentasi, foto dan lain- lain. Arikunto (2013: 137) menjelaskan, bahwa dalam penelitian kualitatif sumber data adalah partisipan dimana data dapat diperoleh. Dalam pengambilan sampling, peneliti memilih sample dengan sengaja. Hal ini dilakukan dengan maksud untuk memperkaya data dari penelitian yang dilakukan karena peneliti menentukan kriteria bagi partisipan tertentu yang akan diwawancara. Partisipan dalam penelitian ini adalah pelestari saweran pengantin yang juga merupakan pelaku aktif kegiatan saweran, yang telah mengabdi di Desa Kadu Gedong Kabupaten Pandeglang dan beberapa informan yang memiliki hubungan dekat/terkait dengan partisipan dan akan berkembang sesuai dengan kebutuhan data.

Partisipan yang dipilih merupakan seseorang yang memiliki kriteria yang sesuai dengan tujuan peneliti. Kriteria tersebut didapat dari survei dan observasi yang telah dilakukan di Desa Kadu Gedong Kabupaten Pandeglang Desa Kadu Gedong Kabupaten Pandeglang sebelumnya. Menurut kerabatnya, partisipan adalah orang yang sangat aktif dan mahir dalam kegiatan saweran penganti di Desa Kadu Gedong Kabupaten Pandeglang. Partisipan telah berpengalaman bertahun-tahun menggeluti dunia saweran pengantin dan telah menjadi pelestari kidung cukup lama, yaitu selama 30 tahun. Dengan demikian, peneliti berkesimpulan bahwa partisipan akan dapat memberikan data yang tepat terkait dengan Saweran Pengantin dan kaitannya dengan makna-makna yang terkandung di dalam teks sawerannya.

Sumber data penelitian ini adalah partisipan, informan, dan dokumen. Metode pengumpulan data dalam penelitian ini menggunakan teknik observasi dan wawancara. Data primer diperoleh dengan melakukan wawancara mendalam dengan teknik semi terstruktur atau wawancara bebas terpimpin kepada partisipan. Teknik wawancara semi terstruktur digunakan agar wawancara tidak berlangsung secara kaku, sehingga mampu menggali data secara mendalam. Selain itu, peneliti beranggapan dengan teknik wawancara ini, maka pertanyaan peneliti dapat berkembang sesuai dengan situasi yang ada, namun tetap terarah pada topik yang terkait dengan Saweran Pengantin dan makna yang dipahami oleh partisipan. Peneliti sengaja tidak menggunakan teknik wawancara yang lain karena dikhawatirkan akan sulit untuk mencapai titik jenuh kematangan informasi yang digali dari partisipan.

\section{HASIL DAN PEMBAHASAN}

\section{Makna Leksikal}

Pada analisis tentang makna leksikal, menggunakan teori Yendra, bahwa makna leksikal juga disebut sebagai makna atau leksem atau kata, ketika kata tersebut berdiri sendiri dalam bentuk dasar maupun bentuk kata turunan dan maknanya merujuk kepada arti yang sebenarnya atau disebut juga dengan makna lambang kebahasaan yang masih bersifat dasar, 
yakni belum mengalami konotasi dan hubungan gramatik (Yendra, 2016: 168).

Bismillah damel wiwitan, mugi gusti nangtayungan

Eulis Asêp nu rêndêngan, mugi aya kasalametan

(Bismillah yang dilakukan pertama, semoga Tuhan melindungi

Eulis Asep yang berendeng, semoga dalam keselamatan)

Bagian ini memiliki kata, /Bismillah/, dengan nama Allah (Retnoningsih, 2017: 91), /pertama/, kesatu, mula-mula sekali; terutama (Retnoningsih, 2017: 376), /Tuhan/, sesuatu yang diyakini, dipuja, dan disembah oleh manusia sebagai yang Mahakuasa, Mahaperkasa, dan sebagainya (Retnoningsih, 2017: 590), /semoga/ mudah-mudahan (Retnoningsih, 2017: 474). Jadi, bagian ini memiliki kata 'bismillah', 'pertama', 'Tuhan', 'semoga', sebagai makna leksikal. Di sisi lain, Pramesti (2021: 134) dalam penelitiannya memaknai tuhan sebagai tujuan doa atau ritual dalam seserahan tumpeng pada adat Indramayu.

Salamet nu pangantênan, ulah aya kakirangan

Sing tiasa sasarengan, sangkan jadi kasenangan

(Selamat pada pengantin, jangan ada kekurangan

Semoga bisa bersama-sama, hingga menjadi kegembiraan)

Bagian ini memiliki kata, /selamat/, terpelihara dari bencana; berarti terhindar dari bahaya (Suharsono dan Retnoningsih, 2017: 469), /pengantin/, orang yang sedang melangsungkan perkawinannya; dinikahkan mempelai; kembang pengantin (Retnoningsih, 2017: 369), /hingga/, batas penghabisan; batas; sampai; sehingga (Retnoningsih, 2017: 169). Jadi, bagian ini memiliki kata 'selamat', 'pengantin', dan 'hingga' sebagai makna leksikal.

\section{Makna Langsung}

Ulah sok tanggah ka luhur, sakaop ningali batur

Ari batur eunggeus mujur, ari urang kalah mundur
(Jangan suka menengadah, karena lihat orang lain

Bila orang lain sudah sukses, tapi kita semakin mundur)

Pada bagian ini, memiliki kata bermakna langsung yakni 'menengadah' yang berarti melihat ke atas, menghadapkan muka ke atas, mengangkat kepala (tidak menunduk). Selain itu, bagian ini memiliki kata 'sukses' yang bermakna suatu yang berhasil, beruntung. Sedangkan, menengadah dimaknai oleh Ulinsa (2020: 82) sebagai bentuk menghindari kesombongan, tetapi tidak juga merendahkan diri terhadap situasi yang diterima.

Eulis tong loba kahayang, di mata engkang keur bingbang

Engkangna têh osok sumbang, jeung carogê tara aman

(Eulis jangan banyak kemauan, terlihat Akang sedang bimbang

Akangnya suka salah, dengan suami jarang tentram)

Bagian ini memiliki kata bermakna langsung yakni 'bimbang' yang berarti suatu perasaan yang tidak tetap hati (kurang percaya), ragu-ragu, merasa khawatir, cemas. Sedangkan kata 'bimbang' juga memiliki makna sebagai suatu upacara atau pesta adat.

Mun Eulis mêrê budi mah, ka carogê mêrê genah

Cik geulis êta baju têh, Akang êta asa bogoh

(Kalau Eulis baik hati, ke suami juga nyaman

Hai cantik itu pakaiannya, Akang merasa cinta)

Bagian ini memiliki kata bermakna langsung yakni 'cinta' yang berarti suka sekali, sayang benar, kasih sekali, terpikat (antara lakilaki dan perempuan), ingin sekali, berharap sekali, rindu, susah ahti (khawatir), risau.

\section{Makna Kiasan}

Pada analisis ini menggunakan teori Chaer tentang makna kiasan atau asosiatif adalah makna kata atau leksem yang didasarkan atas perasaan atau pikiran yang timbul pada penyapa dan pesapa. Makna ini muncul akibat asosiasi perasaan pemakai bahasa terhadap leksem yag 
dilafalkan atau yang didengarnya (Chaer, 2012: 293)

Komo lamun mênta keras, mantak sok mepeuskeun gelas

Êta têh bakat ku caah, banget cinta rejeung bogoh

(Apalagi kalau minta dengan keras, maka akan memecahkan gelas

Itu akan membuat banjir, pada cinta dan kasih sayang)

Bagian ini memiliki makna kiasan bahwa seorang istri janganlah meminta dengan nada keras (bentak) pada suami agar istri tidak dimarahi, sebab itu akan mengakibatkan sakit hati, serta akan membuat istri menangis terhadap perilakunya sendiri.

Lain henteu menang boga, dina eukeur rumah tangga

Tapi Eulis kudu bisa, ngukur ka kujur nu nyata

(Bukannya tidak bisa memiliki, saat rumah tangga

Tapi Eulis harus dapat, mengukur batas kemampuan)

Bagian ini memiliki makna kiasan bahwa seorang istri harus dapat membatasi segala keinginannya serta disesuaikan dengan kemampuan ekonomi yang dimiliki. Sejatinya semua yang diinginkan pasti tercapai, hanya saja keadaan ekonomilah yang membatasi kemauan itu sendiri.

\section{Makna Kultural}

Pada analisis ini menggunakan teori Wakit tentang makna kultural adalah makna bahasa yang dimiliki masyarakat dalam hubungan antara budaya tertentu (Wakit, 2013: 3). Memahami suatu buaya berarti menentukan dan menafsirkan sistem tanda budaya tersebut, tanda tisak mempunyai makna atau konsep tertentu akan tetapu simbol merupakan petenjuk yang semata-mata menghasilkan makna melalui interprestasi. Makna kultural adalah makna bahasa yang dimiliki oleh masyarakat dalam hubungan dengan budaya tertentu (Wakit, 2013: 3).

Saban poê ulah lali, tilih rintih suci ati Têmbongkeun sing bêbêr budi, ciri nyaah ka salaki
(Di kemudian hari jangan lupa, sabar suci hati

Perlihatkan murah hati, ciri sayang pada suami)

Bagian ini memiliki kata 'sabar' bermakna suatu bentuk keteguhan hati menghadapi sikap, ucapan dan lain sebagainya dari suami pada kehidupan rumah tangga, kata 'suci' biasanya bermakna suatu hal yang tercipta dari kebersihan serta sah untuk beribadah, makna di sini merupakan suatu keadaan seorang istri yang selalu menjaga hatinya dari perangai buruk tentang suaminya, kata 'hati' bermakna suatu keikhlasan dan rela hidup dengan seorang lelaki baru serta berumah tqangga dengannya (suami), kata 'perlihatkan' bermakna suatu keharusan bagi istri agar selalu menjaga setiap sikap dan perilakunya dengan suami, kata 'murah hati' bermakna bahwa seorang istri diharuskan untuk selalu baik pada suaminya meskipun suaminya memiliki tabiat yang kurang baik guna menjaga keharmonisan berumah tangga. Jadi bagian ini memiliki makna bahwa seorang istri diharuskan menjaga sepenuh hatinya dengan segala kesabaran yang dimiliki serta menjaga tabiat baik di depan suaminya agar tercipta kerukunan dalam berumah tangga, serta memperlihatkan bahwa istrinya sangat mencintai serta menyayangi suaminya.

\section{Makna Religius}

Nilai-nilai luhur sebagai pondasi karakter bangsa dimiliki oleh setiap suku di Indonesia, seperti halnya yang dikemukakan oleh Wibowo (2012: 23) Religius yang berarti sikap dan perilaku yang patuh dalam melaksanakan ajaran agama yang dianutnya, toleran terhadap pelaksanaan ibadah agama lain, dan hidup rukun dengan pemeluk agama lain.

Bismillah damel wiwitan, mugi gusti nangtayungan

Eulis Asêp nu rêndengan, mugi aya kasalametan

(Bismillah yang dilakukan pertama, semoga Tuhan melindungi

Eulis Asep yang berendeng, semoga dalam keselamatan)

Salamet nu pangantênan, ulah aya kakirangan 
Sing tiasa sasarengan, sangkan jadi kasenangan

(Selamat pada pengantin, jangan ada kekurangan

Semoga bisa bersama-sama, hingga menjadi kegembiraan)

Nilai pendidikan reigius digambarkan pada paragraf pertama dan kedua, yakni tentang doa kepada Tuhan Yang Mahakuasa untuk mendapatkan perlindungan serta keselamatan bagi kedua pengantin agar selalu berbahagia bersama-sama menjadi keluarga yang sakinah mawadah warohmah. Pada kedua paragraf tersebut juga digambarkan sebagai bentuk keikhlasan untuk selalu memohon dan meminta Ridho-Nya sebagai Tuhan semesta alam.

\section{SIMPULAN}

Kajian yang sudah dilakukan tentang simbol dan makna pada teks kawih saweran pernikahan desa Kadu Gedong Pandeglang dapat dirumuskan simpulan Pertama, teks kawih saweran pernikahan memiliki simbol sebagai amanat kepada kedua mempelai, dan menjadi bekal dalam rumah tangga, serta sebagai bentuk suka cita yang dilakukan oleh kedua pasangan tersebut. Kedua, memiliki makna yang terkandung, seperti makna leksikal, makna langsung, makna kiasan, makna gramatikal, dan makna kultural. Ketiga, memiliki nilai-nilai pendidikan karaktrer yang sesuai dengan kriteria bahan ajar di Sekolah Menengah Pertama kelas VII KD 3.13 Mengidentifikasi informasi (pesan, rima, dan pilihan kata) dari puisi rakyat (pantun, syair, dan bentuk puisi rakyat setempat) yang dibaca dan didengar dan 3.14 Menelaah struktur dan kebahasaan puisi rakyat (pantun, syair, dan bentuk puisi rakyat setempat) yang dibaca dan didengar. Dengan demikian, teks kawih saweran pada upacara pernikahan sudah relevan dengan nilai karakter yang di antaranya religus, tanggung jawab, peduli sosial, dan lingkungan yang dapat diajarkan kepada siswa SMP kelas VII.

\section{DAFTAR PUSTAKA}

Abdullah, Wakit. 2013. Kearifal Lokal dalam Bahasa dan Budaya Jawa Masyarakat Nelayan di Pesisir Selatan Kebumen (Sebuah Kajian Etnolinguistik). Disertasi. Surakarta: Universitas Sebelas Maret.

Arikunto, S. 2013. Prosedur Penelitian: Suatu Pendekatan Praktik. Jakarta: Rineka Cipta.

Chaer, Abdul. 2012. Linguistik Umum. Jakarta: Rineka Cipta.

Dewi, R. 2007. Pengukuran Pengetahuan, Sikap dan Kepedulian Siswa SMA pada Lingkungan Hidup (Tesis). Jakarta: Program Pascasarjana Universitas Indonesia.

Littlejohn, Stephen W \& Karen A. Foss.2009. Teori Komunikasi, edisi 9. Jakarta: Salemba Humanika.

Morissan. 2013. Teori Komunikasi. Bogor: Ghalia Indonesia.

Pramesti. Diah. 2021. Makna Leksikal dan Makna Kultural Istilah dalam Tradisi Ngarot di Kecamatan Lelea, Indramayu. Jurnal Kode. 10 (1):.128-137

Rahmah, Rizqa Aulia, dkk. 2020. The Influence of STAD Model Assisted with ALPIN Media Towards The Understanding of Students' Concepts. Jurnal Ilmiah Sekolah Dasar. 4(3): 388-396.

Spradley, James P. 2007. Metode Etnografi. Yogyakarta: Tiara Wacana.

Sugono, D., dkk. 2008 Kamus Besar Bahasa Indonesia Edisi Keempat. Jakarta: PT. Gramedia Pustaka Utama.

Suharsono dan Ana Retnoningsih. 2017. Kamus Besar Bahasa Indonesia. Semarang: Widya Karya

Sutedi, Dedi. 2003. Dasar-Dasar Linguistik Bahasa Jepang. Bandung: Humaniora Utama Press.

Ulinsa. 2020. Representasi Makna Verbal dan Fungsi dalam Pepatah Bahasa Kaili Dialek Rai di Sulawesi Tengah. Semiotika 21(2): 82-92.

Wibowo, Agus. 2012. Pendidikan Karakter, Strategi Membangun Karakter. Bangsa. Yogyakarta: Pustaka Pelajar.

Yendra. 2016. Mengenal Ilmu Bahasa. Yogyakarta: Deepublish. 